\title{
A MUZSIKA VALÓDI HANGJA
}

A harmincas években, az Anschluss előtt játszódik minden idők talán legsikeresebb musicalje a salzburgi kolostorban nevelkedö novíciáról, aki többet foglalkozik az énekléssel, mint a zárdai kötelezettségeivel. Ez A muzsika hangja. A történet nem független a Monarchia bukásától, az I. világháború lesújtó következményétől. Nem véletlen tehát, hogy az 1917-ben Max Reinhardt, Hugo von Hofmannstahl, Richard Strauss, Franz Schalk, Alfred Roller által megalapított Salzburgi Ünnepi Játékok Háza Egyesület révén útnak indított Salzburgi Ünnepi Játékok százéves történetét riportok segítségével bemutató könyv A muzsika valódi hangja címet kapta.

A háború utáni első békeprojektnek tervezett fesztivál az európai kultúra ügyének jelképe lett. Ausztria akkor az egykori monarchia saint-germaini békeszerződés utáni maradványaként élte meg napjait. Sokak szerint ez a kezdeményezés egyike volt az új önmeghatározáshoz vezető lépéseknek.

Az alapötletet az 1876-ban kezdődő Bayreuthi Ünnepi Játékok sikere adta - a karmester Karl Richter már a következő évben felvetette egy salzburgi Mozart-fesztivál gondolatát, amit 1904-ben a színházat megújító Reinhardt, a zenét megújító Richard Strauss és a költői nyelvet virtuózan használó Hofmannstahl élesztett fel, ám pénz híján nem tudott még megvalósítani.

A később megalakult egyesület aztán előteremtette azt is, és 1920. augusztus 22-én, a Salzburgi Dóm előtt megszólaló Hofmannstahl Jedermann (Akárki) címủ misztériumjátékával elkezdődött a száz éve tartó sikersorozat.

Mai arculata, amely szerint együtt érvényesüljön a nyelv és a zene, 1922-re alakult ki, amikor maga Richard Strauss vezényelte Mozart nagyszabású Da Ponte-operái közül a Cosi fan tuttét és a Don Giovannit.

Ebből a tíz évtizedből már közel négyet kísért végig a helyszínen dr. Székely György főorvos, aki gyermekkora óta szimbiózisban él a zenével: hegedün és klasszikus gitáron játszik, ő szorgalmazta a négy orvosból álló Semmelweis Vonósnégyes 1983-as létrejöttét, szervezte és mind a mai napig szervezi fellépéseit, gondoskodik arról, hogy mindig csatlakozzék hozzájuk egy-egy muzsikuskiválóság is, aki nemcsak „emeli az est fényét”, de akitől hihetetlen sokat tanulnak is ezek a kiváló amatőr muzsikusok.

1993-tól már nem csupán zenerajongó, „civil” nézőként, de akkreditált újságíróként köszöntik őt (is) a salzburgi fanfárok.

Az évek során a különböző sajtóorgánumokban publikált beszámolók, esszék egy kötetbe rendezése azonban nem lenne olyan lebilincselő olvasmány, mint amilyen A muzsika valódi hangja. A szerző számos interjút készített a fesztiválok 
résztvevőivel, amelyek az ünnepi játékok történetét felvázoló, a különböző intendánsi korszakokat bemutató fejezetek között, azokat személyessé téve és színesítve jelennek meg.

Az Anschluss és maga a világháború természetesen megálljt parancsolt a Reinhardt, Stefan Zweig és Hofmannstahl nevével fémjelzett programoknak, a fegyverek elhallgatása után azonban feléledt a város kulturális élete. Újból színre vitték a Jedermannt, és elkezdődött a máig tartó sztárparádé: Wilhelm Furtwängler, Karl Böhm, Herbert von Karajan követték egymást a karmesteri dobogón. Karajan elérte, hogy felépítsék a Nagy Házat, hogy ne csak Mozart, de a zenetörténet legkülönbözőbb korszakainak mestermüvei is megszólaljanak. A kor legelismertebb rendezői és szólistái jegyezték az előadásokat. A korszakismertetőkben Székely György különös gonddal emlékezik meg azokról a magyar müvészekröl, akik felléptek ott az évek során.

Az 1992-ig tartó Karajan-időszakot követő évből való a Végh Sándorral készült, igazi zenetörténeti értéket képviselő beszélgetés, amely nemcsak a muzsikus és Bartók zenéje közötti szimbiózisról mesél. Szakemberek számára minden bizonnyal a hangszeresként előadott vonósnégyesek és a dirigensként bemutatott zenekari művek különleges szempontú elemzése jelenti a legtöbbet. A salzburgi fesztiváloktól megigézett olvasó pedig pillanatképet kaphat a sztárkultusz előtti időszakról, amikor még a Mester megszólítás is túlzásnak számított.

A Karajan teremtette Salzburgi Húsvéti Ünnepi Játékok 1992-es rendezvényein mutatkozott be a városban az egyedülálló karriert befutó Marton Éva, aki a 2019-es interjúban már múlt időben beszélt a világsztárok és Salzburg nevének összekapcsolódásáról, sőt, az ő salzburgi pályafutásában nemcsak a muzsikusok, de a lemeztársaságok versengése is központi szerepet játszott.

Karajan magyar sajtófőnökével, Csobádi Péterrel 1994-ben beszélgetett Székely György; a kötetben publikált interjú úgy Karajan, mint a salzburgi fesztiválok és a legmagasabb szintủ zenebiznisz mủhelytitkaiba avatja be az olvasót.

Gerard Mortier (müvészeti) és Hans Landesmann (gazdasági) 1989 és 2011 közötti irányító tevékenysége határozta meg a fesztivál, sőt, fesztiválok „Karajan-éra" utáni történetét, amelyet az operajáték reformja, a modern zene és müvészet térnyerése jellemzett. Megkerülhetetlenné vált a kortárs muzsika. Már 1993-ban több ciklusban összesen huszonöt hangversenyen szólaltak meg kortárs darabok: például Karlheinz Stockhausen, Ligeti György, Kurtág György müvei. Fellépett a Budapesti Fesztiválzenekar Fischer Iván és Eötvös Péter vezényletével és sok más magyar müvész is.

Az 1995-ös, emlékezetes Traviata-előadás a Rost Andreával készült riport fötémája (így, egy szóban, ahogy a zeneművek fötémáját is írjuk). A Riccardo Muti vezényelte előadás a 75. születésnapját ünneplö Salzburgi Játékok egyik fö attrakciója volt a fesztivál tematikáját meghatározó 20. századi bécsi iskola mesterei, Arnold Schönberg, Alban Berg és Anton Webern müvei mellett. A hatalmas 
színpad és a kérdéses kimenetelü rendezés ellenében létrejött interpretáció óriási sikert aratott. A következő évben Solti György volt a szerző riportalanya, s végeredményként egy újabb zenetörténeti csemege született Híd múlt és jelen között címmel. Az annak idején Arturo Toscanini mellett „gyakornokoskodó” karmester, aki a szerző jelenlétében vezényelhette Richard Strauss Rózsalovagját, már a hangrögzítés (akkori) legújabb vívmányait is sikeresen kamatoztatta: ötven éven át készített lemezeket a Decca céggel, mintegy negyven operát és 250 hangszeres művet rögzítettek, számos Grammy-díjat zsebelve be ezekkel.

Mérföldkövet jelentett - természetesen - a 2006-os év: vajon mivel rukkol elő Mozart szülővárosa a szerző születésének 250. évfordulója alkalmából? A 2002 és 2006 között regnáló Peter Ruzicka kortárssá avanzsálta Mozartot, formabontó, ha úgy tetszik polgárpukkasztó operarendezéseket segített színpadra, felújíttatta a kiváló akusztikájú Mozart-házat, megnyitotta a Kis Fesztiválszínházat, ahol a komponista minden színpadi müvét bemutatták.

Az elkövetkező évek a folyamatos újat keresésröl szóltak. Egyre több ritkán játszott zenemúvet mutattak be, az ismert operák rendhagyó felfogásban kerültek színpadra, s ezenközben (ragaszkodva a talán legfontosabb salzburgi tradíciókhoz) sorra érkeztek a sztárok, hiszen Salzburgban fellépni mind a mai napig egyet jelent a nemzetközi elismertséggel, a jók között is a legjobbak klubtagságával.

2007-ben, amikor Ruzicka távozott, a fesztivál vezetésének feladatát öt évre a Scala müvészeti vezetője, a közönség által rajongva ünnepelt Riccardo Muti kapta meg. Az ő ötlete volt egy újabb salzburgi fesztivál, a Salzburgi Pünkösdi Ünnepi Játékok gondolata, amellyel szülőföldje, Nápoly zenéje előtt kívánt tisztelegni. A klasszikus nagymesterek stílusát is meghatározó „nápolyi iskola” alig ismert szerzőinek darabjait tüzte müsorra, óriási sikerrel. Székely György kötete a Pünkösdi Ünnepi Játékok telitalálataként említi Cecilia Bartolit, aki 2012-ben vette át az eseménysorozat müvészeti irányítását, elképesztő leleményeséggel tematizálva a programokat; annak idején az ö újítása volt a tematikusan megszerkesztett koncertprogramok sora, amihez számos énekes csatlakozott az évek során. Így lett a 2012-es fesztivál központi szereplője a szép és rafinált Kleopátra (Szerelem és hatalom), majd az Áldozatok a zenetörténetben, majd a Rossinissimo következett, benne a Bartoli nevétől már elválaszthatatlan Hamupipőkével. És így tovább, évadokon keresztül. S ha valaki meg akarná vádolni Ceciliát, hogy saját magára szabta a müsorokat, ne tegye! A meghívottak között nemcsak kiemelkedő hangszeres művészek (köztük Schiff András) és karmesterek, de akár riválisnak mondható énekesek is voltak. Kálmán Péter is részesülhetett a Bartolival való közös munka számára is feledhetetlen folyamataiban, amelynek kapcsán elbüvölő riport is született Egy buffo is kaphat föszerepet! címmel. És ezen a ponton kapott helyet a Schiff Andrással készült 1998-as beszélgetés is (Költészet és zene). A címből sejteni lehet, hogy elsősorban dalszerzőkről lesz szó; és valóban, az interjúval egyik kedvencének, Schumann-nak hódolt a zongorista. 
Ki gondolná, hogy a napjaink egyik legnagyobb zeneszerzőjének tartott Eötvös Péter nemcsak komponál és dirigál, de elkötelezett híve és rajongója Mozartnak is? Hosszasan mesélt erről a vele készített interjúban, ahogy a kortárs óriásról, Kurtág Györgyről is, akihez egyaránt füzik szakmai és baráti kapcsolatok.

Az utolsó beszélgetések egyikét 2019-ben rögzítette a szerző Várjon Dénessel. A zongorista már huszonöt évesen olyan versenygyözelmek birtokában volt, amelyek feljogosították, hogy Végh Sándorral kamarázhasson a Mozart-házban, a Camerata Salzburg társaságában. A világ ma egyik leggyakrabban foglalkoztatott pianistája azóta is rendszeresen megfordul a Salzburgi Ünnepi Játékokon, és mind a mai napig Végh Sándor számára az etalon. „Magyar vagy, akkor játssz magyarul" - mondta. És Várjon Dénes ma is ehhez tartja magát.

(Székely György: A muzsika valódi hangja. A Salzburgi Ünnepi Játékok magyar szemmel. Szerk.: Ambrus András, Schulz Katalin. Kiadó: Dr. Székely György, Szakmai együttmüködö partner a Corvina Kiadó, 2019)

Tóth Anna

zenetörténész 